\title{
Helping consumers make a more conscious nutritional choice: acceptability of nutrition information at a cafeteria
}

\author{
Giovanna Turconi* ${ }^{*}$ Rosella Bazzano, Carla Roggi and Hellas Cena \\ Department of Applied Health Sciences, Section of Human Nutrition and Dietetics, Faculty of Medicine, \\ University of Pavia, Via Bassi 21, 1-27100 Pavia, Italy
}

Submitted 13 April 2011: Accepted 29 September 2011: First published online 29 November 2011

\begin{abstract}
Objective: A few studies link out-of-home eating to higher energy consumption, overweight and obesity in both adults and children. The present study was undertaken to investigate the nutritional value of meals available in a university cafeteria, in order to develop a target nutritional tool to help consumers make a more conscious nutritional choice.

Design: A cross-sectional study.

Setting: In a university cafeteria in Pavia, northern Italy, the recipes and ingredients of each meal served during the whole year were obtained from the cooks. Energy, protein, fat, carbohydrate and fibre contents were computed for each meal standardized portion. Thirteen pyramid figures, subdivided into three coloured levels, were used to depict the energy and nutrient content of each meal.

Subjects: Four hundred randomly selected customers were interviewed on the cafeteria nutritional proposal.

Results: Foods available in the cafeteria consisted of 216 items and were distributed in the pyramids according to their energy content: the lowest ones at the bottom (green level) and the highest ones at the top (red level), passing through an orange level in the middle. Energy values ranged from $460 \mathrm{~kJ}(110 \mathrm{kcal})$ for a portion of dressed vegetables to $5021 \mathrm{~kJ}(1200 \mathrm{kcal})$ for a pizza. The depicted pyramids were displayed in the cafeteria, so that customers could choose their meal according to its nutritional value. The meals' nutritional content information was perceived very helpful for customers' nutritional choices.

Conclusions: Availability of nutrition information in the cafeteria was well accepted by the customers who could plan their meals according to a more balanced diet.
\end{abstract}

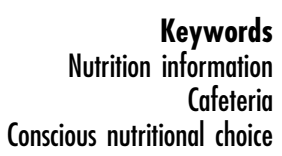

Out-of-home eating (OHE) has increased considerably in past decades to take an important place in the habitual diet $^{(1-5)}$. Although obesity and poor dietary habits are complex multifactorial problems, OHE has been identified as one likely and important contributor ${ }^{(6)}$. Foods from restaurants and other food service establishments are generally high in energy and fat and low in fibre compared with home-prepared foods ${ }^{(6,7)}$, so that a few studies link OHE to higher energy consumption, overweight and obesity in both adults and children ${ }^{(8-10)}$. Indeed, modern lifestyles and time scarcity have contributed to an increase in OHE and the increasing trend is likely to continue ${ }^{(7,11,12)}$. The energy and nutrient intakes of OHE individuals (at restaurants, canteens, cafeterias, fast-food restaurants and similar establishments) may differ from those of people who generally eat at home ${ }^{(13)}$. There are several studies in the USA and Australia focusing on changes in food and energy intakes related to eating locations $s^{(7,11-14)}$, but there is a scarcity of such studies in European countries ${ }^{(2)}$.
Various studies have shown that OHE is associated with higher energy intake due to high nutritional density ${ }^{(7,15-17)}$ or larger portion size ${ }^{(18)}$. Therefore, the catering sector is increasingly recognized as a stakeholder to promote healthy diets and lifestyle ${ }^{(19)}$.

OHE presents additional nutritional challenges when compared with eating at home. Different psychosocial and environmental factors determine what is eaten and customers too often have insufficient access to nutrition

In Italian university towns like Pavia, the university cafeterias are important contributors to OHE consumption of main meals for students, university staff and other workers. It has been shown that cafeterias can contribute to create an obesogenic environment ${ }^{(21,22)}$, but could also represent a place where availability of nutrition information may offer an opportunity to improve customers' $\operatorname{diet}^{(23,24)}$.

The aim of the present study was to carry out an investigation on the nutritional value of the meals offered by a university cafeteria in Pavia, northern Italy, in order information to make a conscious nutritional choice ${ }^{(20)}$. 
to develop a tool for an informed nutritional choice. The outcome of the study is expected to assist customers in planning their meals according to a healthier and more balanced diet.

\section{Materials and methods}

The study was carried out during winter 2008 and spring 2009 in a university cafeteria in Pavia, northern Italy, which is structured both as a restaurant and as a fast-food establishment. Every day about 1000-1200 meals are served during winter and 500-600 during the end of spring and early summer. The cafeteria is frequented by university students, university staff and other workers. The collaboration with the cafeteria personnel and the customers was essential for our study.

\section{Cafeteria menu}

The meals served are combination of first dishes, main dishes, pizza, 'focaccia', sandwiches, cooked and raw vegetables, legumes and potatoes, different types of salad, fruit, desserts and dressing components. Beverages available are mineral water, soft drinks, beer, red and white wine. The quantity of each food component served is known with a fair level of accuracy, as portion sizes are standardized. Specific receptacles are used to serve the portions, i.e. spoon, cup, number of croquettes, number of slices of ham, etc. The accuracy of the standardized portion sizes was verified during a period of 4 weeks by three trained dietitians on a daily basis by random weight measurements of meals served. A list of each food served during the whole year was obtained from the cook together with the recipes and ingredients. The contents of energy, protein, fat, carbohydrates and fibre of the standardized portion size of each meal were computed.

Pyramid figures, subdivided into three coloured levels, were used to depict the energy and nutrient content of each meal.

\section{Customer interviews}

After the depicted pyramids had been displayed in the cafeteria for 2 weeks, 400 customers, randomly selected during a week, were invited to answer a brief interview. Before they had chosen their meal, the customers were interviewed by a dietitian in order to collect the following information: age, gender, weight, height, physical activity level (for computation of BMI and energy requirement), education level, occupation and place of origin. In addition, the following eight questions were asked:

1. 'Do you think it is useful to know the nutritional content of the meals you consume?'

2. 'Do you think that, knowing the meals' nutritional content, you might choose a more balanced menu and improve your diet?'

3. 'What nutritional content do you like to know?'
4. 'Do you think that knowing the meal energy and fat content could help overweight subjects control their diet?'

5. 'Have you changed your food choices at all since you have been informed of the meals' nutritional values?'

6. 'If yes, what do you choose now?'

7. 'Do you consider the cafeteria nutritional proposal useful?'

8. 'Do you think that this proposal could help you to choose correct food associations for a more balanced diet?'

Before the consumption of the meal and drinks, the dietitian observed and registered the food and drink items chosen by each customer, and then the nutritional and energy content of the meal and drinks was computed.

After consumption of the meal, two more questions were asked of each customer:

1. 'Do you know your energy requirement?'

2. 'How many calories do you think you have ingested today with your meal?'

Each customer interview took about $8 \mathrm{~min}$.

\section{Data analysis}

Energy and nutrient content (protein, fat, carbohydrates and fibre) was computed for each meal standardized portion served in the cafeteria by a web program containing the food composition tables of the European Institute of Oncology ${ }^{(25)}$ database.

BMI was computed for each customer as the self-reported weight in kilograms divided by the square of self-reported height in metres. Basal energy requirement was calculated using the equations of $\mathrm{FAO} / \mathrm{WHO} /$ United Nations University $^{(26)}$ and then multiplied by the target physical activity level coefficient ${ }^{(26)}$ as derived from the customer's answers during the interview on questions about physical activity, in order to compute the daily total energy requirement.

Data were analysed using the SPSS for PC statistical software package version 14 (SPSS Inc., Chicago, IL, USA). Descriptive statistics (means and standard deviations) were calculated. Pearson's correlation coefficients and Student $t$ tests were used to study associations and differences between some of the variables investigated. The statistical significance level was set to $P<0.05$ for all tests.

\section{Etbical approval}

The study received ethical approval from Pavia University. All participants had the purpose of the study explained to them, received an information leaflet and provided written consent before participating.

\section{Results}

\section{Meals' nutritional values and pyramid figures}

The list of foods available in the cafeteria and their portion sizes are shown in Table 1, reporting 216 meals 
Table 1 List of meals available in the cafeteria and their portion sizes

\begin{tabular}{|c|c|c|c|c|}
\hline \multirow[b]{2}{*}{ Meals } & \multirow[b]{2}{*}{ No. of meals } & \multicolumn{2}{|c|}{ Portion sizes $(\mathrm{g})$ ready to eat } & \multirow{2}{*}{$\frac{\begin{array}{c}\text { Italian standard } \\
\text { portion sizes }^{(27,28)}\end{array}}{\text { Raw weight }(\mathrm{g})}$} \\
\hline & & Mean & SD & \\
\hline Pasta & 56 & 402 & 87 & 80 \\
\hline Rice & 18 & 443 & 78 & 80 \\
\hline Filled pasta & 13 & 392 & 84 & 180 \\
\hline Meat & 12 & 170 & 23 & 70/100 \\
\hline Fish & 5 & 168 & 31 & $100 / 150$ \\
\hline Eggs & 4 & 172 & 18 & 50 \\
\hline Pizza & 22 & 350 & 37 & - \\
\hline Sandwiches and 'focaccia' & 20 & 241 & 35 & $50^{*}$ \\
\hline Cheese & 13 & 93 & 21 & $50 / 100$ \\
\hline Different dressed salads & 10 & 254 & 36 & 50 \\
\hline Dressed vegetables, legumes and potatoes & 14 & 275 & 48 & 250 \\
\hline Desserts & 12 & 114 & 27 & - \\
\hline Fruit & 9 & 192 & 23 & 150 \\
\hline Salad dressing (1 portion = 1 spoonful) & 8 & 25 & 7 & 10 \\
\hline
\end{tabular}

*Bread, not filled.

grouped into fourteen items. The random weight measurements of the available meals, carried out during a period of 4 weeks by three trained dietitians, showed that most of the portions were large sizes as well as greater than those suggested by the Italian portion standards ${ }^{(27,28)}$.

The meals' nutritional values were reported in dietary pyramids, subdivided into three coloured levels: at the bottom, the green colour, showing that the meals included here can be habitually eaten; in the middle, the orange colour, showing the meals that can be eaten with caution; and at the top, the red colour, showing the meals that must be eaten only occasionally. The energy content was the criterion according to which every meal was depicted in the different levels: at the bottom, the meals with the lowest energy content; in the middle, those with the average values; at the top, those with the highest values. The cut-off points for categorization into the three groups were derived by dividing by three the range between the lowest and the highest energy value for the meal. Each pyramid level reported the mean value and the range for energy and macronutrient content of the meals included within it.

The salads pyramid was slightly different from the others. In this green coloured pyramid, the nutritional values reported corresponded to those of a plain green mixed salad that may be enriched with other ingredients, such as cheese, sausage, meat, würstel, eggs, ham and boiled potatoes, for which only the energy content was provided.

Thirteen pyramids were depicted in total: four for first courses, two for main courses, one for pizzas, one for sandwiches and 'focaccia', one for cheese, one for salads, one for vegetables, one for desserts and one for salad dressings.

The meals reported in the green level represented $32.4 \%$ of the whole meals available in the cafeteria, those in the orange level $39 \cdot 8 \%$ and those in the red level $27 \cdot 8 \%$. The pyramids with the greatest number of meals in the red level were the sandwiches $(n 11)$ and desserts ( $n$ 8) ones, followed by the 'white' dressed pasta $(n 6)$, filled pasta ( $n$ ) and pizzas ( $n$ ) ones.
A few drafts of the pyramids are shown in Figs 1 and 2, while Table 2 reports the energy values and nutrient contents of the meal portion sizes available in the cafeteria distributed in the pyramids' three levels.

For the first courses, energy values ranged from $941 \mathrm{~kJ}$ ( $225 \mathrm{kcal})$ to $2510 \mathrm{~kJ}$ ( $600 \mathrm{kcal})$, for the main courses from $523 \mathrm{~kJ}(125 \mathrm{kcal})$ to $3515 \mathrm{~kJ}(840 \mathrm{kcal})$, for pizza from $2929 \mathrm{~kJ}(700 \mathrm{kcal})$ to $5021 \mathrm{~kJ}(1200 \mathrm{kcal})$, for sandwiches and 'focaccia' from $1464 \mathrm{~kJ}(350 \mathrm{kcal})$ to $3766 \mathrm{~kJ}(900 \mathrm{kcal})$, for cheese from $502 \mathrm{~kJ}(120 \mathrm{kcal})$ to $1506 \mathrm{~kJ}(360 \mathrm{kcal})$, for different dressed salads from 1046 (250 kcal) to $2427 \mathrm{~kJ}$ $(580 \mathrm{kcal})$, for dressed vegetables, legumes and potatoes from $460 \mathrm{~kJ}(110 \mathrm{kcal})$ to $1590 \mathrm{~kJ}(380 \mathrm{kcal})$, and for desserts from $669 \mathrm{~kJ}(160 \mathrm{kcal})$ to $2469 \mathrm{~kJ}(590 \mathrm{kcal})$.

The fat content in each portion was $\geq 20 \mathrm{~g}$ in $36.6 \%$ of the items overall: eight meals in the green level, twentynine meals in the orange level and forty-two meals in the red level (Table 2).

The depicted pyramids were displayed in the cafeteria close to meal distribution, so that each customer could choose his/her meal according to its nutritional value.

\section{Customer interviews}

Out of 400 randomly selected customers with no exclusion criterion, 374 answered the interview $(86.7 \%$ of the customers; 192 males and 182 females). Two hundred and fifty of these respondents were university students, while 124 were either university staff or other workers. Employee was the most represented. Prevalent education level was secondary school degree $(53 \cdot 2 \%$ ), while $29 \cdot 1 \%$ of the respondents had graduated. Both students and workers were mainly from northern Italy (79.9\%). The most physically active were male students (61.3\%), while workers $(58 \cdot 8 \%)$ and female students $(60 \cdot 3 \%)$ were the most sedentary. The mean age was $29 \cdot 2$ (SD $11 \cdot 2$ ) years (range 19-70 years) and $29 \cdot 1$ (SD $12 \cdot 8$ ) years (range $19-73$ years) for males and females, respectively. The mean BMI based on self-reported weight and height was $23 \cdot 5$ (SD $2 \cdot 9) \mathrm{kg} / \mathrm{m}^{2}$ 
"WHITE" DRESSED PASTA

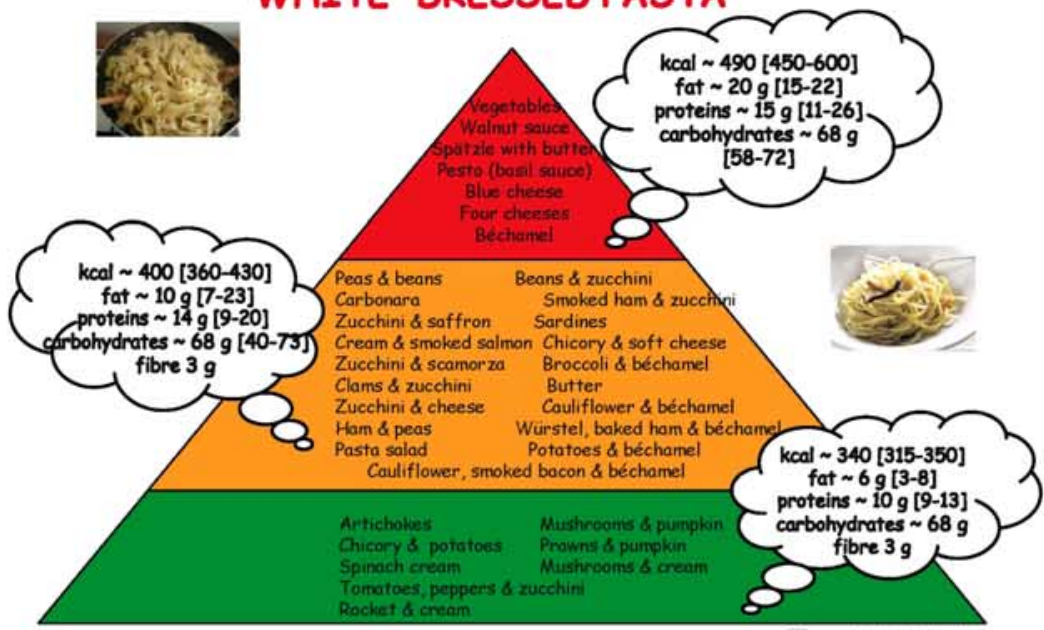

(2)

\section{MAIN COURSES}

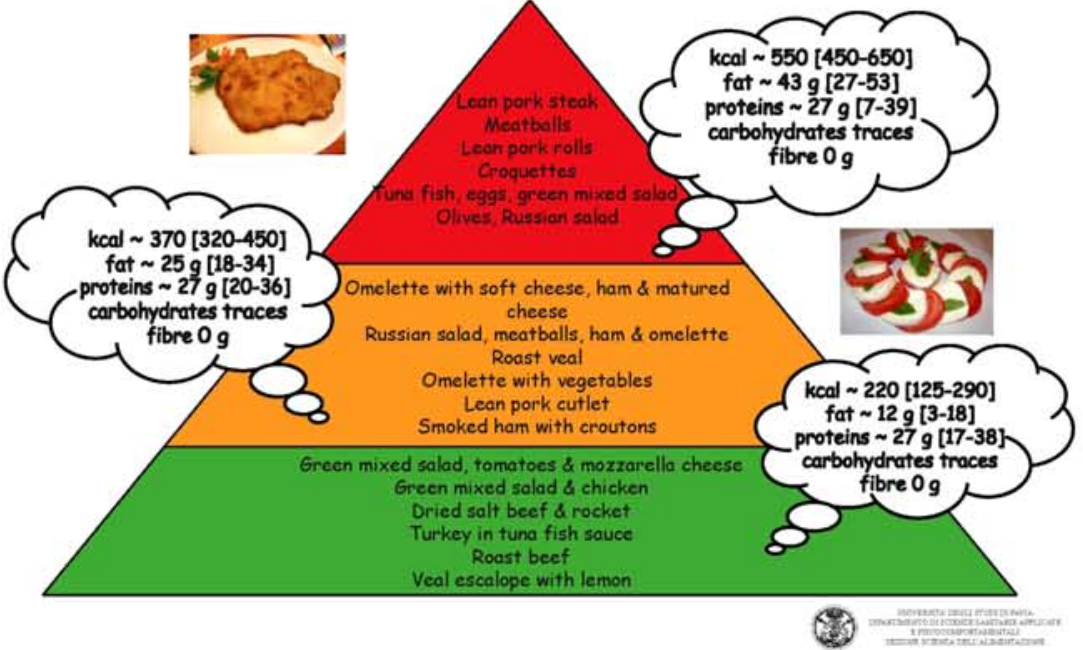

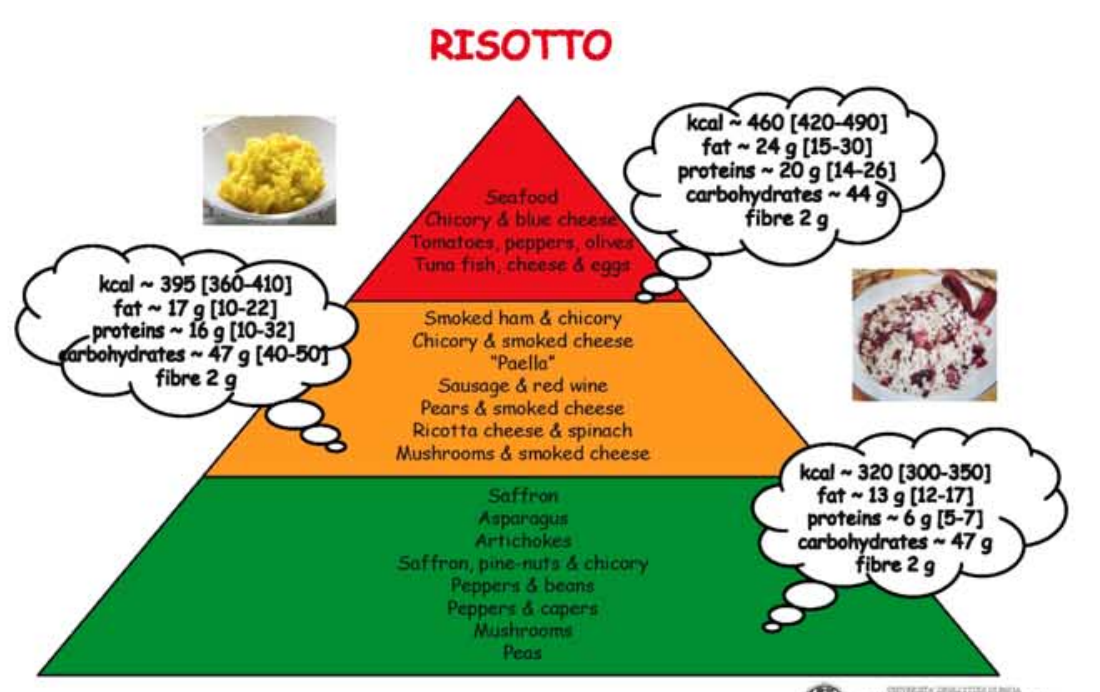

(2) -

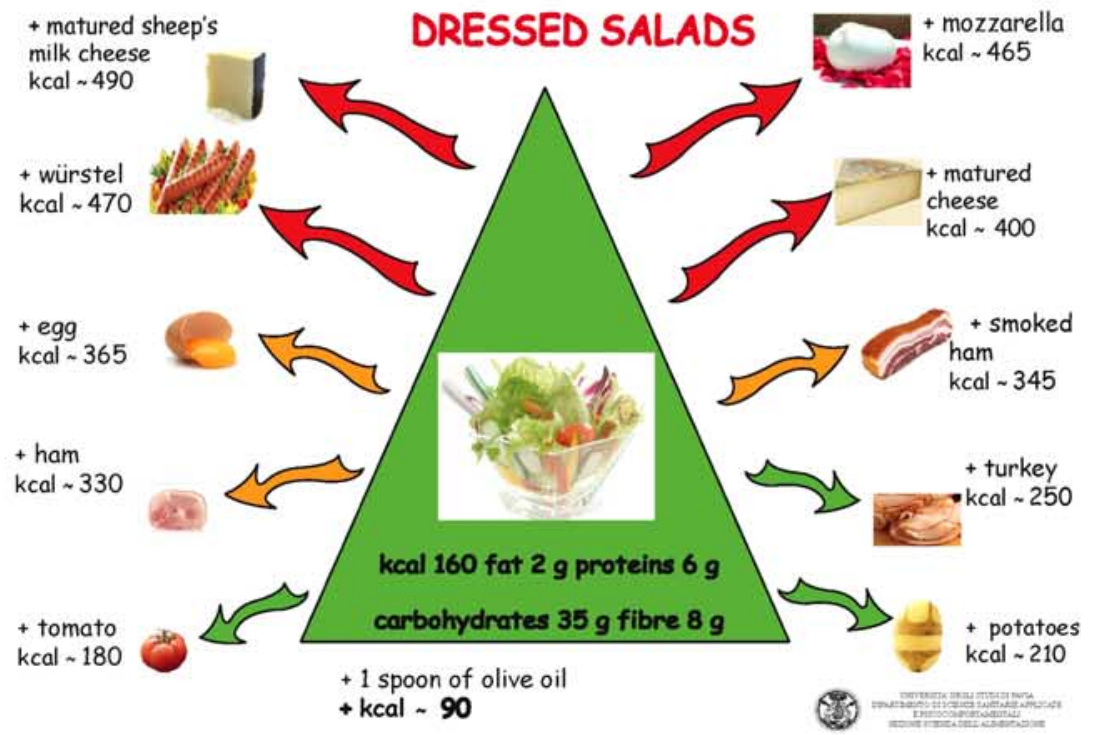

Fig. 1 The pyramids for 'white' dressed pasta, risotto, main courses and dressed salads. Each pyramid level reports the mean value and the range (in square brackets) for energy and macronutrients of the meals included within it (to convert to kJ, multiply kcal by $4 \cdot 184$ ) 

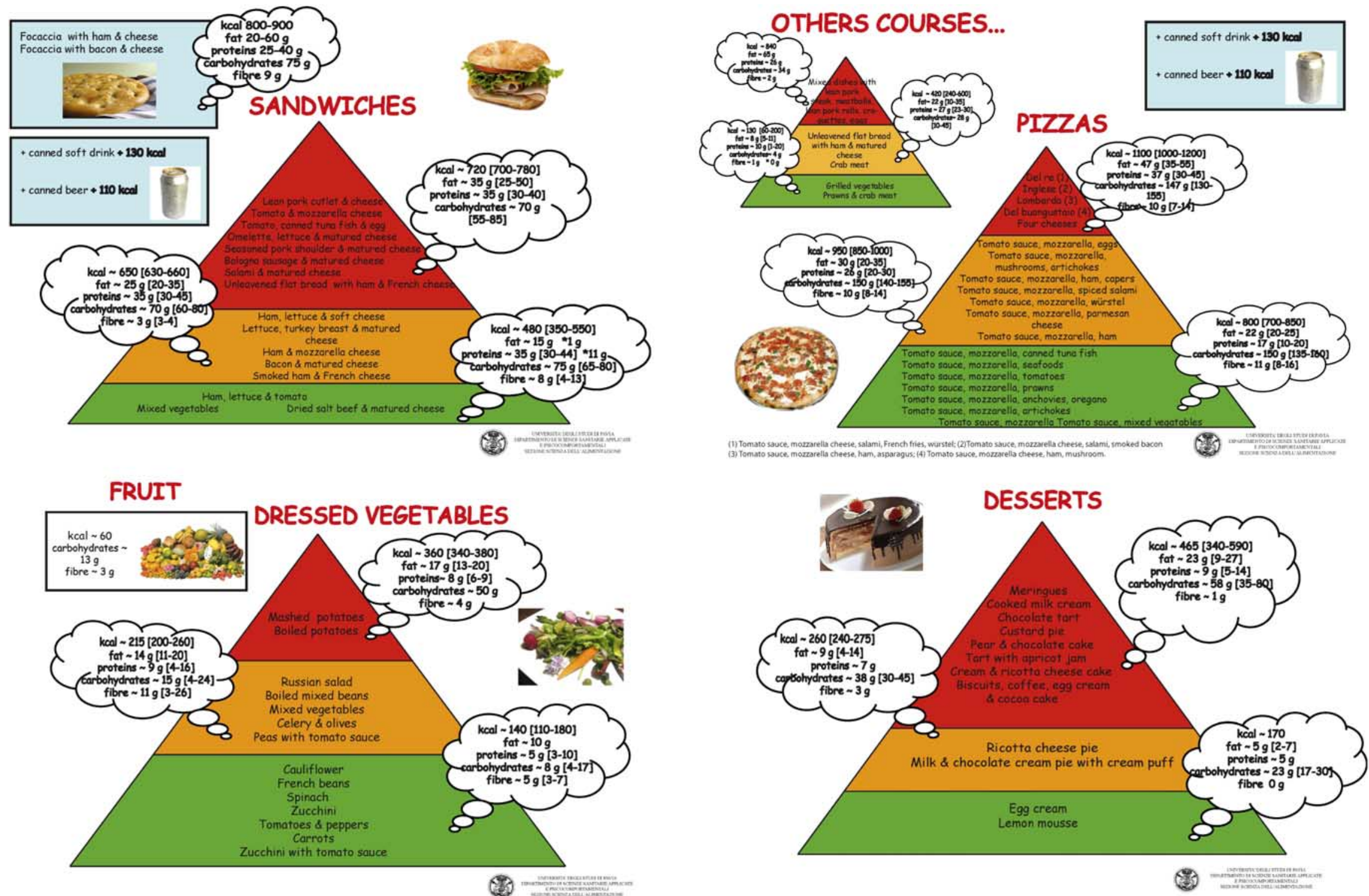

(3) $=$

Fig. 2 The pyramids for sandwiches, pizzas, dressed vegetables and desserts. Each pyramid level reports the mean value and the range (in square brackets) for energy and macronutrients of the meals included within it (to convert to kJ, multiply kcal by $4 \cdot 184$ ) 
Table 2 Energy and nutrient content of the meal portion sizes available at the university cafeteria included in the pyramids' three levels

\begin{tabular}{|c|c|c|c|c|c|c|}
\hline \multirow[b]{2}{*}{ Pyramid } & \multicolumn{2}{|c|}{ Green level } & \multicolumn{2}{|c|}{ Orange level } & \multicolumn{2}{|c|}{ Red level } \\
\hline & Mean & Range & Mean & Range & Mean & Range \\
\hline 'White' dressed pasta & \multicolumn{2}{|c|}{$(n 8)$} & \multicolumn{2}{|c|}{$(n 19)$} & \multicolumn{2}{|c|}{$(n 6)$} \\
\hline Energy (kJ) & 1423 & $1318-1464$ & 1674 & 1506-1799 & 2050 & $1883-2510$ \\
\hline Energy (kcal) & 340 & $315-350$ & 400 & $360-430$ & 490 & $450-600$ \\
\hline Fat (g) & 6 & $3-8$ & 10 & $7-13$ & 20 & $15-22$ \\
\hline Protein (g) & 10 & $9-13$ & 14 & $9-20$ & 15 & $11-26$ \\
\hline $\mathrm{CHO}(\mathrm{q})$ & 68 & $67-68$ & 68 & $40-72$ & 68 & $58-72$ \\
\hline Fibre (g) & 3 & $3-4$ & 3 & $3-4$ & 3 & $3-4$ \\
\hline 'Red' dressed pasta & \multicolumn{2}{|c|}{$(n 12)$} & \multicolumn{2}{|c|}{$(n 9)$} & \multicolumn{2}{|c|}{$(n 1)$} \\
\hline Energy (kJ) & 1548 & $1506-1590$ & 1674 & $1632-1715$ & 2301 & - \\
\hline Eneray (kcal) & 370 & $360-380$ & 400 & $390-410$ & 550 & _- \\
\hline Fat (g) & 8 & $7-9$ & 11 & $10-11$ & 26 & - \\
\hline Protein $(g)$ & 11 & $9-13$ & 12 & $11-14$ & 12 & - \\
\hline $\mathrm{CHO}(\mathrm{g})$ & 68 & $67-68$ & 68 & $67-68$ & 72 & - \\
\hline Fibre (g) & 3 & $3-4$ & 3 & $3-4$ & 3 & - \\
\hline Filled pasta and potato dumplings & \multicolumn{2}{|c|}{$(n 1)^{*}$} & \multicolumn{2}{|c|}{$(n 8)$} & \multicolumn{2}{|c|}{$(n 5)$} \\
\hline Energy (kJ) & 941 & - & 1799 & $1674-1883$ & 2008 & $1883-2259$ \\
\hline Energy (kcal) & 225 & - & 430 & $400-450$ & 480 & $450-540$ \\
\hline Fat $(g)$ & 9 & - & 18 & $17-22$ & 24 & $20-26$ \\
\hline Protein (q) & 7 & - & 14 & $11-16$ & 17 & $15-19$ \\
\hline $\mathrm{CHO}(\mathrm{q})$ & 35 & - & 55 & $50-62$ & 48 & $45-53$ \\
\hline Fibre $(g)$ & 1 & - & 4 & $4-5$ & $\begin{array}{r}40 \\
4\end{array}$ & $4-5$ \\
\hline Risotto & & & & & & 3) \\
\hline Energy (kJ) & 1339 & $1255-1464$ & 1653 & $1506-1715$ & 1925 & $1757-2050$ \\
\hline Energy (kcal) & 320 & $300-350$ & 395 & $360-410$ & 460 & $420-490$ \\
\hline Fat $(\mathrm{g})$ & 13 & $12-17$ & 17 & $10-22$ & 24 & $15-30$ \\
\hline Protein (q) & 6 & $5-7$ & 16 & $10-32$ & 20 & $14-26$ \\
\hline $\mathrm{CHO}(\mathrm{g})$ & 47 & $47-48$ & 47 & $40-50$ & 44 & $42-47$ \\
\hline Fibre $(\mathrm{g})$ & 2 & $2-3$ & 2 & $2-3$ & 2 & $2-3$ \\
\hline Main courses & & & & & & 4) \\
\hline Energy (kJ) & 920 & $523-1213$ & 1548 & $1339-1883$ & 2301 & $1883-2720$ \\
\hline Energy (kcal) & 220 & $125-290$ & 370 & $320-450$ & 550 & $450-650$ \\
\hline Fat $(\mathrm{g})$ & 12 & $3-18$ & 25 & $18-34$ & 43 & $27-53$ \\
\hline Protein (q) & 27 & $17-38$ & 27 & $20-36$ & 27 & $7-39$ \\
\hline $\mathrm{CHO}(\mathrm{g})$ & $\operatorname{Tr}$ & - & $\mathrm{Tr}$ & - & $\mathrm{Tr}$ & - \\
\hline Fibre (g) & 0 & - & 0 & - & 0 & - \\
\hline Special main courses & & & & & & 1) \\
\hline Energy (kJ) & 544 & $251-837$ & 1757 & $1004-2510$ & 3515 & - \\
\hline Energy (kcal) & 130 & $60-200$ & 420 & $240-600$ & 840 & - \\
\hline Fat (q) & 8 & $5-11$ & 22 & $10-35$ & 65 & _- \\
\hline Protein (g) & 10 & $1-20$ & 27 & $23-30$ & 26 & - \\
\hline $\mathrm{CHO}(\mathrm{g})$ & 4 & $4-4$ & 28 & $10-45$ & 34 & - \\
\hline Fibre (g) & 1 & $1-1$ & 2 & $2-3$ & 2 & - \\
\hline Pizza & & & & & & 5) \\
\hline Energy (kJ) & 3347 & $2929-3556$ & 3975 & $3556-4184$ & 4602 & $4184-5021$ \\
\hline Energy (kcal) & 800 & $700-850$ & 950 & $850-1000$ & 1100 & $1000-1200$ \\
\hline Fat $(\mathrm{q})$ & 22 & $20-25$ & 30 & $20-35$ & 47 & $35-55$ \\
\hline Protein (g) & 17 & $10-20$ & 26 & $20-30$ & 37 & $30-45$ \\
\hline $\mathrm{CHO}(\mathrm{g})$ & 150 & $135-160$ & 150 & $140-155$ & 147 & $130-155$ \\
\hline Fibre (g) & 11 & $8-16$ & 10 & $8-14$ & 10 & $7-14$ \\
\hline Sandwiches and 'focaccia' & & & & & & 11) \\
\hline Energy $(\mathrm{kJ})$ & 2008 & $1464-2301$ & 2720 & $2636-2761$ & 3556 & $3347-3766$ \\
\hline Energy (kcal) & 480 & $350-550$ & 650 & $630-660$ & 850 & $800-900$ \\
\hline Fat $(\mathrm{g})$ & 15 & $12-16$ & 25 & $20-35$ & 40 & $20-60$ \\
\hline Protein (g) & 35 & $30-44$ & 35 & $30-45$ & 32 & $25-40$ \\
\hline $\mathrm{CHO}(\mathrm{q})$ & 75 & $65-80$ & 70 & $60-80$ & 75 & $70-80$ \\
\hline Fibre (g) & 4 & $4-5$ & 5 & $3-6$ & 5 & $4-6$ \\
\hline Cheeses & & & & & & 6) \\
\hline Energy (kJ) & 628 & $502-795$ & 1025 & $920-1172$ & 1381 & $1297-1506$ \\
\hline Energy (kcal) & 150 & $120-190$ & 245 & $220-280$ & 330 & $310-360$ \\
\hline Fat $(\mathrm{g})$ & 8 & $7-9$ & 20 & $15-25$ & 25 & $20-30$ \\
\hline Protein (g) & 15 & $10-20$ & 15 & $15-20$ & 25 & $20-30$ \\
\hline $\mathrm{CHO}(\mathrm{q})$ & 0 & - & 0 & _- & 0 & - \\
\hline Fibre (g) & 0 & - & 0 & - & 0 & - \\
\hline
\end{tabular}


Table 2 Continued

\begin{tabular}{|c|c|c|c|c|c|c|}
\hline \multirow[b]{2}{*}{ Pyramid } & \multicolumn{2}{|c|}{ Green level } & \multicolumn{2}{|c|}{ Orange level } & \multicolumn{2}{|c|}{ Red level } \\
\hline & Mean & Range & Mean & Range & Mean & Range \\
\hline Different dressed salads & \multicolumn{2}{|c|}{$(n 3)$} & \multicolumn{2}{|c|}{$(n 3)$} & \multicolumn{2}{|c|}{$(n 4)$} \\
\hline $\begin{array}{l}\text { Energy (kJ) } \\
\text { Energy (kcal) }\end{array}$ & $\begin{array}{r}1213 \\
290\end{array}$ & $\begin{array}{c}1046-1423 \\
250-340\end{array}$ & $\begin{array}{r}1820 \\
435\end{array}$ & $\begin{array}{c}1757-1904 \\
420-455\end{array}$ & $\begin{array}{r}2280 \\
545\end{array}$ & $\begin{array}{c}2050-2427 \\
490-580\end{array}$ \\
\hline $\begin{array}{l}\text { Dressed vegetables, legumes and potatoes } \\
\text { Energy (kJ) } \\
\text { Energy (kcal) } \\
\text { Fat }(\mathrm{g}) \\
\text { Protein }(\mathrm{g}) \\
\text { CHO }(\mathrm{g}) \\
\text { Fibre }(\mathrm{g})\end{array}$ & $\begin{array}{r}586 \\
140 \\
10 \\
5 \\
8 \\
5\end{array}$ & $\begin{array}{l}\text { 7) } \\
460-753 \\
110-180 \\
10-11 \\
3-10 \\
4-17 \\
3-7\end{array}$ & $\begin{array}{r}900 \\
215 \\
14 \\
9 \\
15 \\
11\end{array}$ & $\begin{array}{l}\text { 5) } \\
837-1088 \\
200-260 \\
11-20 \\
4-16 \\
4-24 \\
3-26\end{array}$ & $\begin{array}{r}1506 \\
360 \\
17 \\
8 \\
50 \\
4\end{array}$ & $\begin{array}{l}\text { 2) } \\
\text { 1423-1590 } \\
340-380 \\
13-20 \\
6-9 \\
50-51 \\
4-5\end{array}$ \\
\hline $\begin{array}{l}\text { Desserts } \\
\text { Energy (kJ) } \\
\text { Energy (kcal) } \\
\text { Fat }(\mathrm{g}) \\
\text { Protein }(\mathrm{g}) \\
\text { CHO }(\mathrm{g}) \\
\text { Fibre }(\mathrm{g})\end{array}$ & $\begin{array}{r}711 \\
170 \\
5 \\
5 \\
23 \\
0\end{array}$ & $\begin{array}{l}\text { 2) } \\
669-753 \\
160-180 \\
2-7 \\
4-5 \\
17-30 \\
-\end{array}$ & $\begin{array}{r}1088 \\
260 \\
9 \\
7 \\
38 \\
3\end{array}$ & 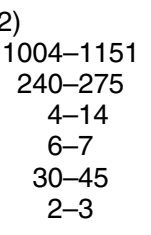 & $\begin{array}{r}1946 \\
465 \\
23 \\
9 \\
58 \\
1\end{array}$ & $\begin{array}{l}\text { 8) } \\
\text { 1423-2469 } \\
340-590 \\
9-27 \\
5-14 \\
35-80 \\
1-2\end{array}$ \\
\hline $\begin{array}{l}\text { Salad dressing ( } 1 \text { portion = } 1 \text { spoonful) } \\
\text { Energy (kJ) } \\
\text { Energy (kcal) } \\
\text { Fat }(\mathrm{g}) \\
\text { Protein }(\mathrm{g}) \\
\text { CHO }(\mathrm{g}) \\
\text { Fibre }(\mathrm{g})\end{array}$ & $\begin{array}{r}105 \\
25 \\
4 \\
0 \\
0 \\
0\end{array}$ & 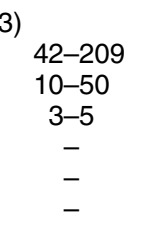 & $\begin{array}{r}669 \\
160 \\
8 \\
0 \\
0 \\
0\end{array}$ & 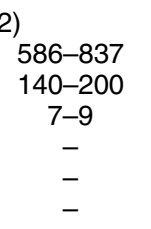 & $\begin{array}{r}1297 \\
310 \\
15 \\
0 \\
0 \\
0\end{array}$ & $\begin{array}{l}\text { 3) } \\
\text { 1213-1381 } \\
290-330 \\
10-20 \\
- \\
- \\
-\end{array}$ \\
\hline
\end{tabular}

$\mathrm{CHO}$, carbohydrates; $\mathrm{Tr}$, trace.

*Potato dumplings.

and $21 \cdot 2(\mathrm{sD} 3 \cdot 3) \mathrm{kg} / \mathrm{m}^{2}$ for males and females, respectively. Of these respondents, $76 \cdot 2 \%$ were normal weight, $14 \cdot 1 \%$ were overweight (19.3\% of males and $8 \cdot 8 \%$ of females) and $2.9 \%$ were obese. The underweight prevalence was $6 \cdot 8 \%(2 \cdot 6 \%$ of males and $11 \cdot 0 \%$ of females $)$. Mean age was not significantly different between male and female respondents, while the prevalence of overweight and underweight differed significantly between genders $(P<0.01$ in both cases). The estimated daily energy requirement was 12456 (SD 1464) kJ (2977 (SD 350) $\mathrm{kcal}$ ) and 8778 (sD 791) kJ (2098 (sD 189) kcal) for males and females, respectively, while that for lunch was about $4979 \mathrm{~kJ}$ (1190 kcal; males) and $3510 \mathrm{~kJ}(839 \mathrm{kcal}$; females).

Table 3 shows the respondents' answers to the interview questions for the whole sample and by gender. Most of the respondents answered 'a lot' to both the first and second question $(56.5 \%$ and $55.4 \%$, respectively), while more than a third of them answered 'enough'. Just under half $(46 \cdot 6 \%)$ of the respondents reported that they were interested in knowing the energy and fat content of the foods they choose, while $31.6 \%$ were interested in knowing the complete nutritional value of the meals (question 3). The majority of respondents (68.5\%), 10.3\% of whom were overweight and obese, answered 'a lot' and $29 \cdot 1 \%$ answered 'enough' to the fourth question.

Of the respondents, $71.4 \%$ reported they had modified their food choice for a healthier diet (question 5); while
$45 \cdot 5 \%$ of them reported to choose foods lower in calories and fat (question 6). Moreover, $57 \cdot 6 \%$ and $38.9 \%$ of the respondents answered 'a lot' and 'enough', respectively, to the seventh question and $52 \cdot 8 \%$ and $43.3 \%$ of respondents, respectively, answered 'a lot' and 'enough' to the eighth question.

About a fifth (21.5\%) of the respondents answered 'I don't know' to the question 'Do you know your energy requirement?' Pearson's correlation coefficients between the energy requirements computed by the dietitians and those estimated by the respondents were significantly correlated both for males and females $(r=0 \cdot 75 ; P<0 \cdot 001$ and $r=0.77 ; P<0.001$ respectively) and independent of education and occupational levels as well as BMI.

Only $10 \cdot 4 \%$ of respondents answered 'I don't know' to the question 'How many calories do you think you have ingested today with your meal?' Those who answered yes, supposed 2962 (SD 1577) kJ (708 (SD 377) kcal; males) and 2853 (SD 1259) kJ (682 (sD 301) kcal; females). The mean energy value of the meal consumed on the interview day, computed by the dietitians, was 3038 (SD 1213) kJ (726 (sD 290) kcal) and 2887 (SD 1180) kJ (690 (sD 282) kcal) for males and females, respectively, with the following mean percentages from nutrients: 16 (SD 3) \% from protein, 30 (SD 2) \% from fat and 54 (SD 6) \% from carbohydrates in males and 14 (SD 2) \% from protein, 28 (SD 3) \% from fat and 58 (SD 7) \% from carbohydrates in females. Wine, beer and soft drinks were consumed by only a few customers. 
Table 3 Interview answers of the total sample and by gender (all values in \%)

\begin{tabular}{|c|c|c|c|}
\hline \multirow[b]{2}{*}{ Question } & \multicolumn{3}{|c|}{ Answer } \\
\hline & Total & Males & Females \\
\hline \multicolumn{4}{|c|}{ 1. Do you think it is useful to know the nutritional content of the meals you consume? } \\
\hline A lot & $56 \cdot 5$ & $54 \cdot 2$ & $58 \cdot 8$ \\
\hline Enough & $37 \cdot 7$ & $39 \cdot 1$ & $36 \cdot 3$ \\
\hline Not at all & $5 \cdot 8$ & $6 \cdot 7$ & $4 \cdot 9$ \\
\hline \multicolumn{4}{|c|}{$\begin{array}{l}\text { 2. Do you think that, knowing the meal nutritional content, you might choose a more balanced menu } \\
\text { and improve your diet? }\end{array}$} \\
\hline A lot & $55 \cdot 4$ & $52 \cdot 6$ & $58 \cdot 2$ \\
\hline Enough & $39 \cdot 0$ & $40 \cdot 1$ & $37 \cdot 9$ \\
\hline Not at all & $5 \cdot 6$ & $7 \cdot 3$ & 3.9 \\
\hline \multicolumn{4}{|c|}{ 3. What nutritional content do you like to know? } \\
\hline Calories and fat & $46 \cdot 6$ & $37 \cdot 7$ & $52 \cdot 9$ \\
\hline All nutrients & $31 \cdot 6$ & $30 \cdot 2$ & $33 \cdot 0$ \\
\hline Nothing & $22 \cdot 8$ & $27 \cdot 0$ & $18 \cdot 7$ \\
\hline \multicolumn{4}{|c|}{$\begin{array}{l}\text { 4. Do you think that knowing the meal energy and fat content could help overweight subjects control } \\
\text { their diet? }\end{array}$} \\
\hline A lot & $68 \cdot 5$ & $67 \cdot 2$ & $69 \cdot 8$ \\
\hline Enough & $29 \cdot 1$ & $30 \cdot 2$ & $28 \cdot 0$ \\
\hline Not at all & $2 \cdot 4$ & $2 \cdot 6$ & $2 \cdot 2$ \\
\hline \multicolumn{4}{|c|}{$\begin{array}{l}\text { 5. Have you changed your food choices at all since you have been informed of the meals' nutritional } \\
\text { values? }\end{array}$} \\
\hline Yes & $71 \cdot 4$ & $64 \cdot 8$ & $78 \cdot 0$ \\
\hline No & $28 \cdot 6$ & $30 \cdot 2$ & $27 \cdot 1$ \\
\hline \multicolumn{4}{|l|}{ 6. If yes, what do you choose now? } \\
\hline Foods lower in calories and fat & $45 \cdot 5$ & $42 \cdot 4$ & $48 \cdot 7$ \\
\hline Foods higher in fibre & $10 \cdot 4$ & $10 \cdot 4$ & $10 \cdot 4$ \\
\hline Foods higher in carbohydrates & $11 \cdot 2$ & $11 \cdot 5$ & $11 \cdot 0$ \\
\hline \multicolumn{4}{|c|}{ 7. Do you consider the cafeteria nutritional proposal useful? } \\
\hline A lot & $57 \cdot 6$ & $53 \cdot 1$ & $62 \cdot 1$ \\
\hline Enough & 38.9 & $42 \cdot 2$ & $35 \cdot 7$ \\
\hline Not at all & $3 \cdot 4$ & $4 \cdot 7$ & $2 \cdot 2$ \\
\hline \multicolumn{4}{|c|}{$\begin{array}{l}\text { 8. Do you think that this proposal could help you to choose correct food associations for a more } \\
\text { balanced diet? }\end{array}$} \\
\hline A lot & $52 \cdot 8$ & $47 \cdot 4$ & $58 \cdot 2$ \\
\hline Enough & $43 \cdot 3$ & $46 \cdot 4$ & $40 \cdot \overline{2}$ \\
\hline Not at all & 3.9 & $6 \cdot 2$ & $1 \cdot 6$ \\
\hline
\end{tabular}

The paired Student $t$ test showed the difference between the supposed calories ingested and those really consumed was not significant; Pearson correlation coefficients between the supposed calories ingested and those really consumed were significant both for males and females $(r=0 \cdot 78 ; \quad P<0 \cdot 001$ and $r=0 \cdot 76 ; \quad P<0 \cdot 001$, respectively).

\section{Discussion}

The present study evaluated the menu available in a university cafeteria in order to produce a target nutritional tool for an informed nutritional choice and help customers in planning their meals according to a healthier and more balanced diet. The menu was wide and varied, containing 216 food items. The customers could choose all the foods they wanted to eat and then paid for the foods chosen.

The random weight measurements of the meals available, carried out during a period of 4 weeks, showed that most of the portion sizes were large (Table 1) and greater than those recommended by the Italian portion standards ${ }^{(27,28)}$. This is in line with recent trends reporting a continuous increase in portion sizes in industrialized countries, especially in the USA $^{(18)}$ and The Netherlands ${ }^{(29)}$. Therefore, about $40 \%$ and $28 \%$ of the meal portion sizes available in the cafeteria had a slightly high energy content (orange level) and a very high energy content (red level), respectively, especially 'white' dressed pasta, pizza, sandwiches and desserts. Moreover the fat content was often high $36.6 \%$ of the items overall contained $\geq 20 \mathrm{~g}$ fat/portion; Table 2 ). This is in agreement with data in the literature ${ }^{(6,7,13)}$ reporting that foods from restaurants, canteens, cafeterias and similar establishments are generally high in energy and fat when compared with home-prepared foods. In addition, various studies have shown that $\mathrm{OHE}$ is associated with higher energy intakes due to the meals' higher energy density ${ }^{(2,6,7,15-17)}$ or larger portion size (30-33). $^{\text {. }}$

Special suggestions aimed at lowering the energy content of such meals were given to the cooks, in terms of reducing the portion size and decreasing the fat content in the recipes. Only $32 \cdot 4 \%$ of the meal portion sizes showed an acceptable energy content (green level).

Concerning the interviewed customers, their age range was wide, given that a third of them were workers and 
some of them were retired. Most of these respondents had normal weight $(76 \cdot 2 \%)$, while all of the underweight respondents $(6 \cdot 8 \%)$ were students and most of them were females. This shows the widespread behaviour of young women to pursue the desire of thinness. Overweight respondents were found especially among men $(19 \cdot 3 \% v \cdot 14 \cdot 1 \%)$, only a few were obese $(3 \cdot 6 \%$ of males and $2 \cdot 2 \%$ of females). Prevalence rates of overweight and obesity in our sample were well below the Italian national data $^{(34)}$ reporting in 2005 that $42.5 \%$ of males and $26 \cdot 6 \%$ of females were overweight and $10.5 \%$ and $9 \cdot 1 \%$, respectively, were obese. We cannot say if OHE is associated with the prevalence rates of overweight and obesity in our sample, as some studies have shown ${ }^{(6,8-10,16,21,22,31-33)}$, since in the interview we did not ask customers how long they had been eating in the cafeteria and if their weight had increased during that period of time. This is a limitation of our study.

Knowing the nutritional content of the meals was very useful for respondents, since they thought it may be helpful in choosing a more balanced menu and thus improving their diet. Slightly more than a third would like to know the content of all nutrients. Indeed most of the respondents, $10 \cdot 3 \%$ of whom were overweight, were interested in knowing the energy and fat contents of the foods presuming this could be very useful for overweight individuals in order to control their diet. We may suppose that overweight individuals are concerned with their weight status and prone to improve it.

The supposed calories ingested and those really consumed on the interview day were not significantly different; this shows that most of the customers interviewed could compute the actual energy content of their meals by means of the depicted pyramids.

The majority $(71 \cdot 4 \%)$ of respondents claimed to have changed their lunch after knowing the foods' nutritional content, by choosing meals lower in energy and fats, but this cannot be confirmed since we have not investigated their intakes before the intervention. It would had been very interesting to assess the nutritional content of the meals consumed by the participants before the depicted pyramids had been displayed in the cafeteria and then compare it with the meals ingested after the nutrition information was available. We could not carry out this assessment and this is a limitation of our study.

The energy content of the meal eaten on the interview day computed by the dietitians, accounting for 3038 (SD 1213) kJ (726 (sD 290) kcal) in males and 2887 (SD 1180) kJ (690 (SD 282) kcal) in females, represents $25 \%$ and $33 \%$ of the daily energy requirement for males and females, respectively. We know that these percentages are lower than those recommended for lunch (about 40\% of the daily energy requirement); nevertheless, since lunch time during the working day is very short, it is well known that most people today habitually consume only one course with sometimes vegetables and fruit, and have a more plentiful dinner.
The energy percentage from fat of the meal eaten on the interview day amounted to 30 (SD 2) \% and 28 (SD 3) \% for males and females, respectively; values which are more than acceptable. We did not ask the cooks what foods were consumed less after the dietary pyramid figures had been displayed in the cafeteria, and this is a limitation of our study.

Most of the respondents $(96 \cdot 5 \%)$ considered the cafeteria nutritional proposal as useful. It is interesting to note that the $55 \cdot 4 \%$ of respondents who find that the nutritional information might help them to improve their diets are more precise in estimating their intake and are less overweight.

We consider that the pyramid figure depicted in three coloured levels may be a much more effective tool than a food list aimed at helping customers to a conscious nutritional choice, in a nutrition education process.

In the USA, the number of restaurants and other food service establishments providing nutrition information has increased over the last 10 years, since the Surgeon General and the National Academies' Institute of Medicine recommended that nutrition information should be available to customers at restaurants and since legislature and the US Congress addressed this issue ${ }^{(35)}$. Of those restaurants with nutrition information, $86 \%$ provide information also on the company website ${ }^{(35)}$.

In Italy this initiative is not widespread. Nutritional and health policy and nutrition education programmes aimed at decreasing overweight and obesity rates and improving diet quality should promote availability of nutrition information on menus (on posters, pyramid figures, brochures) in chain restaurants and other food service establishments.

\section{Conclusions}

The availability of nutrition information in the cafeteria was well accepted by customers, who could use it as a simple tool to improve their diet, planning their meals according to a healthier and more balanced dietary pattern. Since the pyramid figures are immediately comprehensible we propose that this initiative should be promoted in all food service establishments, with the objective of providing customers with a simple tool for making an informed nutritional choice.

\section{Acknowledgements}

This research received no specific grant from any funding agency in the public, commercial or not-for-profit sectors. There are no financial or other contractual agreements that might cause conflicts of interest. The authors' contributions were as follows. G.T.: study design, data analysis, interpretation of the results, preparation of manuscript, supervisor; R.B.: menu nutritional data elaboration, development of dietary pyramids, customer interviews; C.R.: study 
design, supervisor; H.C.: study design, data analysis, interpretation of the results, preparation of manuscript, supervisor. The authors wish to thank the cafeteria staff, university students and customers for their cooperation during data collection. Special credit goes to the dietitians of the University Graduate Course of Dietitians (Elisa Merelli, Carlotta Stanglini and Valentina Rabaglia) for their enthusiasm during the whole study.

\section{References}

1. Orfanos P, Naska A, Trichopoulos D et al. (2007) Eating out of home and its correlates in 10 European countries. The European Prospective Investigation into Cancer and Nutrition (EPIC) study. Public Health Nutr 10, 1515-1525.

2. Kearney JM, Hulshof KF \& Gibney MJ (2001) Eating patterns - temporal distribution, converging and diverging foods, meals eaten inside and outside of the home implications for developing FBDG. Public Health Nutr $\mathbf{4}$, 693-698.

3. Guthrie JF, Lin BH \& Frazao E (2002) Role of food prepared away from home in the American diet, 1977-78 versus 1994-96: changes and consequences. J Nutr Educ Behav 34, 140-150.

4. Lachat CK, Huybregts LF, Roberfroid DA et al. (2009) Nutritional profile of foods offered and consumed in a Belgian university canteen. Public Health Nutr 12, 122-128.

5. Nago ES, Lachat CK, Huybregts L et al. (2010) Food, energy and macronutrient contribution of out-of-home foods in school-going adolescents in Cotonou, Benin. Br J Nutr $\mathbf{1 0 3}$ 281-288.

6. McCrory MA, Fuss PJ, Hays NP et al. (1999) Overeating in America: association between restaurant food consumption and body fatness in healthy adult men and women ages 19 to 80 . Obes Res 7, 564-571.

7. Kant AK \& Graubard BI (2004) Eating out in America, 1987-2000: trends and nutritional correlates. Prev Med 38, 243-249.

8. Bowman SA, Gortmaker SL, Ebbeling CB et al. (2004) Effects of fast-food consumption on energy intake and diet quality among children in a national household survey. Pediatrics 113, 112-118.

9. Thompson OM, Ballew C, Resnicow K et al. (2004) Food purchased away from home as a predictor of change in BMI Z-score among girls. Int J Obes Relat Metab Disord 28 , 282-289.

10. Zoumas-Morse C, Rock CL, Sobo EJ et al. (2001) Children's patterns of macronutrient intake and associations with restaurant and home eating. J Am Diet Assoc 101, 923-925.

11. Nielsen SJ, Siega-Riz AM \& Popkin BM (2002) Trends in energy intake in US between 1977 and 1996: similar shifts seen across age groups. Obes Res 10, 370-378.

12. Jabs J \& Devine CM (2006) Time scarcity and food choices: an overview. Appetite 47, 196-204.

13. Roos E, Sarlio-Lähteenkorva S \& Lallukka T (2004) Having lunch at a staff canteen is associated with recommended food habits. Public Health Nutr 7, 53-61.

14. Burns C, Jackson M, Gibbons C et al. (2002) Foods prepared outside the home: association with selected nutrients and body mass index in adult Australians. Public Health Nutr 5, 441-448.

15. McCrory MA, Fuss PJ, Saltzman E et al. (2002) Dietary determinants of energy intake and weight regulation in healthy adults. J Nutr 130, 2S Suppl., 276S-279S.
16. Prentice AM \& Jebb SA (2003) Fast foods, energy density and obesity: a possible mechanistic link. Obes Rev 4, 187-194.

17. Satia JA, Galanko JA \& Siega-Riz AM (2004) Eating at fastfood restaurants is associated with dietary intake, demographic, psychosocial and behavioural factors among African Americans in North Carolina. Public Health Nutr 7, 1089-1096.

18. Nielsen SJ \& Popkin BM (2003) Patterns and trends in food portion sizes, 1977-1998. JAMA 289, 450-453.

19. World Health Organization (2007) Proposed Second WHO European Action Plan for Food and Nutrition Policy 2007-2012. Copenhagen: WHO Regional Office for Europe; available at http://www.euro.who.int/data/ assets/pdf_file/0017/74402/E91153.pdf

20. The Keystone Center (2006) The Keystone Forum on Awayfrom-Home Foods: Opportunities for Preventing Weight Gain and Obesity. Washington, DC: The Keystone Center; available at http://keystone.org/files/file/about/publications/ Forum_Report_FINAL_5-30-06.pdf

21. Bell AC \& Swinburn BA (2004) What are the key food groups to target for preventing obesity and improving nutrition in schools? Eur J Clin Nutr 58, 258-263.

22. Utter J, Scragg R, Schaaf D et al. (2008) Relationships between frequency of family meals, BMI and nutritional aspects of the home food environment among New Zealand adolescents. Int J Behav Nutr Phys Act 23, 50-58.

23. López-Frías M, Nestares T, Iañez I et al. (2005) Nutrient intake adequacy in schoolchildren from a Mediterranean area (southern Spain). Influence of the use of the school canteen. Int J Vitam Nutr Res 75, 312-319.

24. Prell HC, Berg MC, Jonsson LM et al. (2005) A school-based intervention to promote dietary change. $J$ Adolesc Health 36, 529-534.

25. Salvini S, Parpinel M, Gnagnarella P et al. (2008) Banca dati di composizione degli alimenti per studi epidemiologici in Italia. Milan: Istituto Europeo di Oncologia.

26. World Health Organization (1985) Energy and Protein Requirements, Report of a Joint FAO/WHO/UNU Meeting. WHO Technical Report Series no. 724. Geneva: WHO.

27. Società Italiana di Nutrizione Umana (1996) Standard Quantitativi delle porzioni. In Livelli di assunzione raccomandati di energia e nutrienti per la popolazione Italiana - LARN, revisione 1996. Rome: SINU.

28. Ministero delle Politiche Agricole e Forestali, Istituto Nazionale di Ricerca per gli Alimenti e la Nutrizione (2003) Linee Guida per una Sana Alimentazione Italiana, revisione 2003. http://www.inran.it/LG2003.htm (accessed March 2011).

29. Steenhuis IH, Leeuwis FH \& Vermeer WM (2010) Small, medium, large or supersize: trends in food portion sizes in The Netherlands. Public Health Nutr 13, 852-857.

30. Diliberti N, Bordi PL, Conklin MT et al. (2004) Increased portion size leads to increased energy intake in a restaurant meal. Obes Res 12, 562-568.

31. Ledikwe JH, Ello-Martin JA \& Rolls BJ (2005) Portion sizes and the obesity epidemic. J Nutr 135, 905-909.

32. Levitsky DA \& Youn T (2004) The more foods young adults are served, the more they overeat. J Nutr 134, 2546-2549.

33. Rolls BJ, Morris EL \& Roe LS (2002) Portion size of food affects energy intake in normal-weight and overweight men and women. Am J Clin Nutr 76, 1207-1213.

34. Ministero della Salute (2007) Sovrappeso ed obesità in Italia. Le dimensioni del problema, Dicembre 2007. http:// www.ccm-network.it/documenti_Ccm/convegni/convegno SIAN/5dic/Greco.pdf (accessed March 2011).

35. Wootan MG \& Osborn M (2006) Availability of nutrition information from chain restaurants in the United States. Am J Prev Med 30, 266-268. 